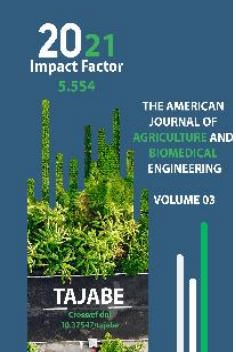

Journal Website: https://theamericanjou rnals.com/index.php/ta jabe

Copyright: Original content from this work may be used under the terms of the creative commons attributes 4.0 licence.

\section{Ensuring Chemical Safety Of Flour And Bakery Products In Surkhandarya}

\author{
Kurbonov Jamshed Majidovich \\ Doctor Of Technical Sciences, Professor Of Samarkand Institute Of Economics And Service, \\ Republic Of Uzbekistan
}

Kholturaev Khontura Kuvvatovich

Independent Researcher, Termez State University, Republic Of Uzbekistan

\title{
ABSTRACT
}

At present, due to changing ecological situation in the country, unfavourable weather conditions, uneven operation of industrial enterprises, especially the use of chemicals in agriculture, etc. (Pollution, increased waste, weakened control) a certain amount of different elements in the composition of food.

\section{KEYWORDS}

Foodstuffs, bakery products, Decree, Indicator criteria, flour.

\section{INTRODUCTION}

In this regard, the Presidential Address to the Oliy Majlis and many other resolutions and decrees set objectives for measures to further ensure food security in the country $[1,2]$.

Since bread from foodstuffs is a foodstuff that people consume on a daily basis, in addition to the fact that its production is of great importance in the national economy, it is important to make sure that it is safe for the human body when consumed.

At present, $18-20 \%$ of the total industrial production in Uzbekistan consists of food products, the bulk of which are bakery products, reaching an average of 920,000 tonnes per year. 
The American Journal of Agriculture and Boimedical Engineering (ISSN - 2689-1018)

One of the most important scientific studies is the presence of factors that change the pathological state of the human organism in various types of food poisoning, especially the presence of toxic elements, and their effects on the human body. Main part. Along with the rest of the world Uzbekistan produces wide assortment of bakery products, while in foreign countries the average volume of bread production per capita in industrial scale is 128 $\mathrm{kg}$, in Uzbekistan now is $50-60 \mathrm{~kg}$ (including home bread $-19.8 \mathrm{~kg}$ ) and the rest is made in small workshops, ovens and at home.
The range of bakery products differs mainly in the chemical composition and energy value of the technology by which they are made.

Republic of Uzbekistan (01 38 -03) "Sanitary norms of food raw material safety langan7 approved by the decision of the Chief State Sanitary Doctor of the Republic of Uzbekistan on August 12, 2003, the table shows the values of sanitary norms of toxic elements in the chemical safety of bread and flour products.

Table1

\section{Sanitary standards for toxic elements in the chemical safety of bakery and flour products}

\begin{tabular}{|l|c|c|c|c|}
\hline \multirow{2}{*}{ No } & Indicator criteria & $\begin{array}{c}\text { 2003 No. 7.12.08 } \\
\text { Unit of } \\
\text { measure }\end{array}$ & $\begin{array}{c}\text { 100 g of } \\
\text { product } \\
\text { Decree of the Chief } \\
\text { State Sanitary } \\
\text { Doctor of the } \\
\text { Republic of } \\
\text { Uzbekistan. }\end{array}$ & $\begin{array}{c}\text { Flour products } \\
\text { Security criterion }\end{array}$ \\
\hline $\mathbf{1}$ & Sulphur & $\mathrm{Mg} / \mathrm{kg}$ & 0.5 & Bakery products \\
\hline $\mathbf{2}$ & Trsenic elements & 0.35 & Flour products \\
& & $\mathrm{Mg} / \mathrm{kg}$ & 0.2 & Bakery products \\
\hline $\mathbf{3}$ & Cadmium & $\mathrm{Mg} / \mathrm{kg}$ & 0.1 & Flour products \\
\hline
\end{tabular}


The American Journal of Agriculture and Boimedical Engineering (ISSN - 2689-1018)

\begin{tabular}{|c|c|c|c|c|}
\hline & & & 0.07 & Bakery products \\
\hline 4 & Mercury & $\mathrm{Mg} / \mathrm{kg}$ & 0.03 & $\begin{array}{l}\text { Flour products } \\
\text { Bakery products }\end{array}$ \\
\hline 5 & Cuprum & $\mathrm{Mg} / \mathrm{kg}$ & 0.015 & $\begin{array}{l}\text { Flour products } \\
\text { Bakery products }\end{array}$ \\
\hline 6 & Zincum & $\mathrm{Mg} / \mathrm{kg}$ & $\begin{array}{l}10 \\
50\end{array}$ & $\begin{array}{l}\text { Flour products } \\
\text { Bakery products }\end{array}$ \\
\hline \multicolumn{5}{|c|}{ Mycotoxins } \\
\hline 1 & Aflotoxin $\mathrm{B}_{1}$ & & 0.00015 & Impossible \\
\hline 2 & Desoxyn and Tenol & & 0.05 & Impossible \\
\hline 3 & Zearalenone & & 0.005 & Impossible \\
\hline 4 & $\mathrm{~T}-2$ toxin & & 0.05 & Impossible \\
\hline \multicolumn{5}{|c|}{ Radionucleoids } \\
\hline 1 & Cesium - 137 & & 40 & $\mathrm{~Bq} / \mathrm{kg}$ \\
\hline 2 & Strontium - 90 & & 20 & $\mathrm{~Bq} / \mathrm{kg}$ \\
\hline
\end{tabular}

In our work the object of research is flour produced by JSC "Surkhandonmahsulotlar" (Termez), "Shurchidonmksualolat" LLC, "Sariosiyo Don" LLC, "Khleb Kolipli" LLC "ZILOLA CAPITAL SAVDO" and "Baysun Kut Baraka". x We determined the quantity and quality of toxic elements in pasta products.

The laboratory tests are conducted mainly in the Surkhandarya branch of SUE "Uz Tekt" in Termez. It took place in the "Food and Agricultural Products Testing Laboratory" of the Termez State University Laboratory.

\section{METHODOLOGY}

Amount of mycotoxin chemical toxins in flour, bread and pasta was

determined by common (colorimetric, chromatographic, polarimetric, etc.) Methods [3].

Dry matter content was determined by drying flour at $105^{\circ} \mathrm{C}$, dough and bread at $130^{\circ} \mathrm{C}$ according to GOST 21094-75 to total mass in an SESH-1 cabinet. Total acidity of flour was determined by Chizhov V.N. In the method (GOST 9404) iron element is fixed according to Ozdst 104-2006. 


\section{RESULTS OBTAINED}

Chromatograms of toxic elements cadmium, arsenic, lead, mercury, zinc and copper and mycotoxins as well as iron element were obtained from 1st grade wheat flour produced by JSC "Surkhandonmakhsulotlar" (Termez). The chromatogram plot showed that the flour contained only zinc: $1.8 \mathrm{mg} / \mathrm{kg}$; we see that the iron content is $20 \mathrm{mg} / \mathrm{kg}$. Tests were carried out under laboratory conditions at $48 \%$ relative humidity and $220^{\circ} \mathrm{C}$. The total acidity was 1.20 .

A similar study was carried out on 1st grade wheat flour obtained from 4 dosages of Shurchidonmaxsulotlar OJSC: dosage number 1 contained zinc $-1.9 \mathrm{mg} / \mathrm{kg}$; number 2 da-2.0; number 3 da-1.8; and number 4 at 2.2; iron element -30. 25, 30. showed presence and acidity $25 \mathrm{mg} / \mathrm{kg}$ : 0.9, 0.8, 1.0, 0.80. Relative humidity in the laboratory $54 \%$, temperature 200 C.

The 1st grade wheat produced by Sarioshio Don Ltd consisted of zinc-16.0 mg/kg, iron 60.0 $\mathrm{mg} / \mathrm{kg}$, acidity -0.80 , laboratory relative humidity 48\%, temperature Toxins and mycotoxins were not detected.

Studies have shown that the presence of zinc and iron (within the required standards) in bread and bakery products is safe for the human body, harmless and even useful in the diet, as they serve to satisfy the daily requirement for zinc and iron.

In our study, organoleptic evaluation of toxic elements and their quality of pasta products "Kolipli bread" and "Baysun Kut Baraka" of "ZILOLA CAPITAL SAWDO" obtained the above mentioned results and their chemical safety and quality requirements of SanKM No 0283 2010 confirmed the answer.

\section{CONCLUSION}

Flour produced in Surkhandarya showed the absence of toxic and mycotoxic elements, only the presence of zinc and iron, their risk of consumption and their chemical safety. The bread and bakery products meet the requirements for their organoleptic characteristics.

\section{REFERENCES}

1. President Shavkat Mirziyoyev's Address to the Oliy Majlis newspaper Zarafshon, 25 January 2020, no. 10-11, 4 pp.

2. Presidential Decree No. PQ-3680 of 26 April 2018 on measures to further ensure the country's food security.

3. Faiziev Y.S., Kurbonov Y.M. "Physicochemical methods of food research", T. "Ilm-Zia", 2009, 268 p. 